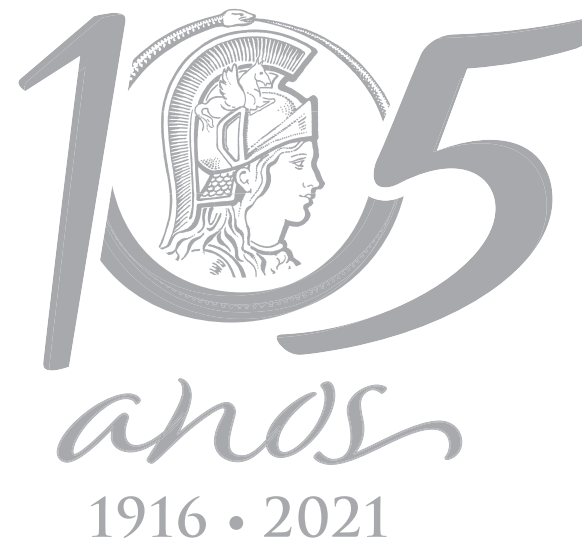

$1916 \cdot 2021$

\title{
MICROBIOLOGY
}

\section{First record of Trypanosoma sp. (Kinetoplastea: Trypanosomatidae) parasiting Rhinella major in the Brazilian Amazon}

\author{
TÁSSIO A. COÊLHO, DARLISON C. DE SOUZA, RICARDO A. KAWASHITA-RIBEIRO \& \\ LINCOLN L. CORRÊA
}

\begin{abstract}
Rhinella major is one of the component species of the Rhinella granulosa group and is distributed in the neotropical region of the South American continent, being found in anthropized environments. The occurrence of trypanosomes in anurans involves a yet unknown diversity of species and hosts. In the present study, we aimed to describe the first record of Trypanosoma sp. at $R$. major as a new host. Of the species captured, four were positive for trypomastigote forms of Trypanosoma sp. The morphometry of the trypomastigote forms revealed parasitemia by only one morphotype. There is a need for reports and studies of parasite-host relationships in anurans and a lack of records regarding hemoparasite diversity linked to the Rhinella granulosa group.
\end{abstract}

Key words: Amphibians, Brazil, hemoparasites and trypanosomatids.

\section{INTRODUCTION}

Amphibians are animals that live in the most diverse habitats, playing an important role in the food webs, contributing to the regulation of invertebrates in natural environments and anthropic areas. Furthermore, they are hosts of a variety of parasites, showing no signs of disease (O'Rourke \& Rosenbaum 2015). The invertebrate hosts and vectors of anuran trypanosomes are related to the habitat of these animals, with hirudinea and hematophagous arthropods reported as the main vectors (Bailey 1962, Anderson \& Ayala 1968, Siddall \& Desser 1992). Relatively, little is known about vectors of trypanosomes of amphibians (Bardsley \& Harmsen 1973, Martin \& Desser 1991, Johnson et al. 1993). The descriptions of all the records of Trypanosoma species found parasitizing anurans are based on morphological aspects observed in the trypomastigote form in the peripheral blood
(Martin et al. 2002). Due to the plasticity of these hemoflagellates, the species may differ in body size and shape, in the position of the nucleus and the kinetoplast, as well as in the degree of development of the undulating membrane and flagellum (Martin et al. 2002).

Rhinella major, Müller and Helmich, 1936 is a component species of the Rhinella granulosa group, Spix, 1824 and is distributed in the Neotropical region of the South American continent. These anurans are characterized by their small parotid gland, warty skin and well developed cranial ridges (Narvaes \& Rodrigues 2009). Adult males have a variable length of 35.8 to $75.8 \mathrm{~mm}$ while females range from 33.9 to 81.1 $\mathrm{mm}$, have a dorsum with dark spots scattered or nearby, forming a mosaic, with a creamcoloured and non-pigmented belly (Narvaes \& Rodrigues 2009).

Despite the lack of knowledge about the pathological effects of the parasite-host 
relationship involving anuran trypanosomes, most reports suggest a nonpathogenic relationship (Desser 2001). However, high rates of parasitemia can damage the health of hosts, especially in the early forms of their life cycle (Bardsley \& Harmsen 1973). Studies in the European and North American continents have shown that the introduction of exotic trypanosomes into new habitats has potential lethality for native amphibian populations (Bardsley \& Harmsen 1973). In this study, we describe the morphology and morphometry of the first record of Trypanosoma sp. parasitizing the $R$. major species in the Brazilian Amazon, also addressing data on prevalence, intensity and abundance of infection.

\section{MATERIALS AND METHODS}

Between June 20 and 22 2018, 44 specimens of $R$. major were collected by an active search in the area of direct influence of the Curuá-Una Hydroelectric Power Plant, in the municipal region of Santarem, in the west of the state of Pará, Brazil, at the coordinates $2^{\circ} 48^{\prime} 52.00^{\prime \prime} \mathrm{S}$, 54ำ17'56.66"O.

The collected specimens were individualized in plastic bags and sent to the Curuá-Una scientific base of the Universidade Federal do Oeste do Pará (UFOPA), for night-time blood sampling and collection procedures (Johnson et al. 1993). In a laboratory environment, the subjects were anaesthetized and euthanized using (2\%) Lidocaine Hydrochloride and their weight and snout-vent length (SVL) in millimetres was measured. The blood was collected by cardiac puncture using syringes containing EDTA (10\%). It was used to make panchromatic-stained blood extensions using Fast Panoptic (Laborclin ${ }^{\circledR}$ Brazil), to evaluate the Trypanosomatidae morphotypes. Individuals of R. major were deposited in the Herpetology Collection of the Laboratory of Ecology and Animal Behavior - LECAN of UFOPA for use in studies involving endoparasites, ecology and taxonomy (access numbers \#UFOPA-H 1295-1335).

The blood extensions were examined for trypanosomes with optical microscope. The parasites were photographed using a Zeiss Axioplan optical microscope with an Axiocam ERc $5 S$ camera. The Zen Blue 2 software package was used to determine the morphometric characteristics of trypanosomes were measured according to Desser (2001) and Borges et al. (2016) (Figure 1).

The parameters of prevalence, mean abundance and mean intensity were calculated according to Bush et al. (1997). The Spearman coefficient (rs) was used to determine possible correlations between parasite abundance and SVL and weight (Zar 2010). The BrayCurtis similarity test and distance indices were used with the Past. 3.0 program to verify possible morphological similarities with the

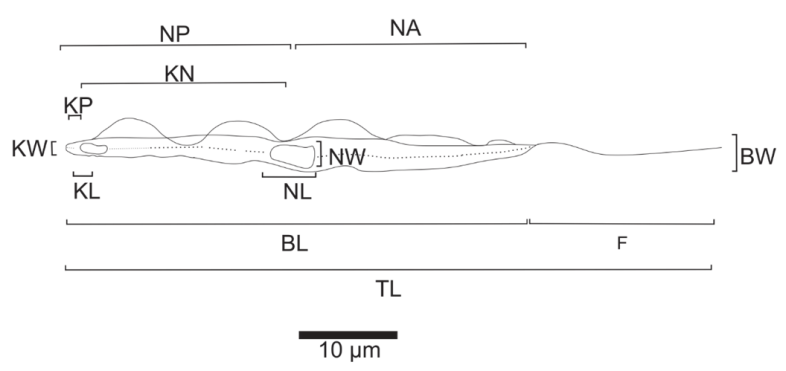

Figure 1. Morphometric localization of the regions of Trypanosoma sp. measured, with values in $\mu \mathrm{m}$, of total body length with flagellum (TL), body length along the midline (BL), body width at the center of the nucleus (BW), length of the free flagellum (F), nucleus length (NL), nucleus width in the central portion (NW), distance from the center of the nucleus to the anterior extremity (NA), distance from the center of the nucleus to the posterior extremity (NP), distance from the center of the kinetoplast to the center of the nucleus (KN), kinetoplast length (KL), kinetoplast width (KW) and distance from the center of the kinetoplast to the posterior extremity (KP). 
Trypanosoma species validated by França 1925, Woo 1969, Martin \& Desser 1990, Ferreira et al. 2007, Lemos et al. 2008, Malysheva 2009, Ferreira Jigdas et al. (2015) and Bernal \& Pinto (2016).

\section{Ethical responsibilities of authors}

The collection of anurans for this study was authorized by the Brazilian government through the Biodiversity Authorization and Information System - (SISBIO no 52610-1). This study was approved by the Animal Use Committee of the Federal University of Western Pará (Authorization $n^{\circ}$ 0320180024). All the procedures performed are by the principles adopted by the Colégio Brasileiro de Experimentação Animal - COBEA.

\section{RESULTS}

Of the 44 captured specimens of $R$. major (35 males and 9 females), four males (9.09\%) presented positivity for trypomastigote forms, with mean weight $(\bar{x}=13.5 ; \mathrm{s}= \pm 1.7 \mathrm{~g})$ and mean SVL ( $\bar{x}=51.9 ; \mathrm{s}= \pm 1.7 \mathrm{~mm})$. Parasite mean abundance was 0.31 and with mean intensity of 3.5 parasites per infected host. Spearman analyzes revealed no correlation between host SVL and parasite abundance ( $p>0.05)$, nor with host weight and parasite abundance ( $p>0.05)$.

When comparing morphometry with valid amphibian trypanosomes species using the Bray-Curtis similarity index, the trypomastigote forms found in the present study (Table I) showed a similarity of $96 \%$ to Trypanosoma fallisi (Martin \& Desser 1990). Grouping in an isolated class (Figure 2), providing evidence for a morphometric identification. Despite the morphometric similarity, it is still not possible to associate at the species level, due to the morphological and morphometric parasite plasticity (Spodareva et al. 2018).

For the morphological study, twenty specimens of the only morphotype found of Trypanosoma sp. were analyzed, presenting a body that is longer than wide, from two to three flexions, with shapes varying from $\mathrm{S}$ and C. The present flagellum represents on average one-third of the total length, with two to four flexions. The cytoplasm presents granulations with two to three vacuoles in the anterior region and the nucleus presents an oval shape, positively displaced to the posterior

Table I. Matrix of morphological similarity between Trypanosoma sp. and valid species of Trypanosoma spp. anuran parasites in accordance with Ferreira et al. $(2007,2008)$ and Bernal \& Pinto (2016).

\begin{tabular}{|c|c|c|c|c|c|c|c|c|}
\hline & T. tungare & T. sp* & $\begin{array}{c}\text { T. } \\
\text { fallisi }\end{array}$ & $\begin{array}{c}\text { T. } \\
\text { chattoni }\end{array}$ & $\begin{array}{c}\text { T. } \\
\text { rotatorium }\end{array}$ & $\begin{array}{c}\text { T. } \\
\text { ranarum }\end{array}$ & $\begin{array}{c}\text { T. } \\
\text { neveulemairei }\end{array}$ & T. mega \\
\hline T. tungare & 1 & 92.803 & 94.076 & 62.111 & 78.920 & 87.388 & 66.866 & 75.807 \\
\hline T. sp* & 92.803 & 1 & 96.034 & 62.778 & 79.282 & 85.711 & 60.363 & 78.512 \\
\hline T. fallisi & 94.076 & 96.034 & 1 & 63.439 & 79.824 & 85.119 & 63.689 & 80.010 \\
\hline T. chattoni & 62.111 & 62.778 & 63.439 & 1 & 67.107 & 58.601 & 33.218 & 61.064 \\
\hline T. rotatorium & 78.920 & 79.282 & 79.824 & 67.107 & 1 & 75.239 & 66.530 & 59.786 \\
\hline T. ranarum & 87.388 & 85.711 & 85.119 & 58.601 & 75.239 & 1 & 56.424 & 81.494 \\
\hline T. neveulemairei & 66.866 & 60.363 & 63.689 & 33.218 & 66.530 & 56.424 & 1 \\
\hline T. mega & 75.807 & 78.512 & 80.01 & 61.064 & 59.786 & 81.494 & 36.179 & 36.179 \\
\hline
\end{tabular}

Present study*. 


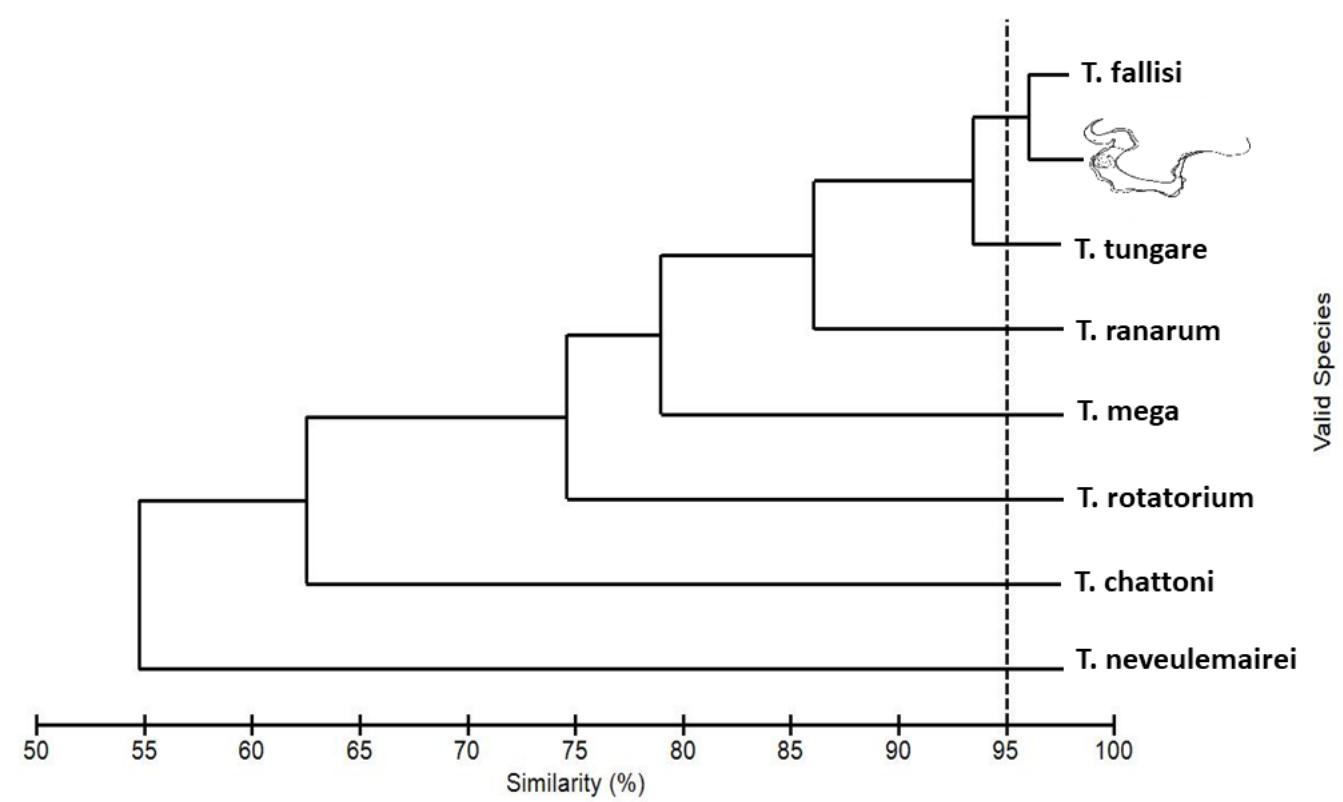

Figure 2.

Dendrogram of morphometric similarity between valid species of trypanosomes for anurans and morphotype identified in Rhinella major collected in Curuá-Una, Santarém, Pará (Brazil).

region of the body with absent cariosoma. In the posterior region, two to three vacuoles are observed, being predominantly located near the nucleus. The kinetoplast presents a shape varying from oval to circular, displaced to the margin of the cytoplasmic membrane, having a distance between the posterior extremity of easy visualization, as well as the undulating membrane.

Morphometric analyzes of Trypanosoma sp. showed that in R. major (Figure 3) was infected by a morphotype of these hemoparasites (Figure 4), and the measurements are presented in Table II.

\section{DISCUSSION}

The present study identified low prevalence rates, mean intensity and mean abundance of Trypanosoma sp. in R. major. Indeed, these parasites appear to be found at a low frequency in these host. Leal et al. (2009) found a prevalence of $20 \%$ in 40 anurans captured in the Brazilian states of Mato Grosso do Sul and São Paulo.
Besides, Ferreira et al. (2007) reported prevalence rates of $36 \%$ of infection in 75 anurans collected in the Amazon biome and a study performed by Desser (2001) in Costa Rica, trypanosomes occur in $12 \%$ of anurans from seven species.

However, Spodareva et al. (2018) found in two lakes in Kiev, Ukraine region, a high prevalence of isolated amphibian trypanosomes. Their work used fewer individuals, when compared to our study, totalling eight trypanosomes isolates of 11 individuals in an Oxbow lake (prevalence of $73 \%)$ and three of 12 individuals in an acidic peatbog (prevalence of 25\%).

In a pathological study of blood parasites, using 140 specimens of the species Hoplobatrachus rugulosus (Rice Field Frogs) in Thailand, revealed prevalence of Trypanosoma rotatorium-like (11.4\%), Trypanosoma chattoni (22.2\%) and other hemoparasites were detected: Hepatozoon sp. (5.7\%) and Lankesterella minima (7.1\%). Also, histopathological study was conducted in liver, kidney, lungs and spleen, but no evidence of pathological lesions associated with trypanosomes was found, only for Hepatozoon sp. and Lankesterella 
minima (Sailasuta et al. 2011). Parasitism by trypanosomes in amphibians is not uncommon and is mostly reported as nonpathogenic (Wright 2006, Densmore \& Green 2007).

In our study, no physical changes were found in hosts corroborating with Bardsley \& Harmsen (1973) which describe pathogenicity caused by Trypanosoma spp. in anurans is an extremely difficult phenomenon to establish, as it does not result in changes in the physical development of the host.

Trypanosomes of anurans are traditionally described based on their host and geographical origin, but this approach is weakened when the extreme polymorphism and plasticity of trypomastigote forms is considered (Ferreira et al. 2007). Recently, Rodrigues et al. (2019) described Trypanosoma sp. parasitizing two amphibian species from Brazilian midwest using morphology and morphometry. The morphological and morphometric study of trypanosomes continues to be used for the description and validation of new hosts and records of new distributions (Miyata \& Yong 1990, Desser 2001, Lemos et al. 2008, Leal et al. 2009).

Using Bray-Curtis similarity indices, the present study corroborates the morphometric characterization and descriptions of the trypanosomes, providing statistical support for the morphological determination of the Trypanosoma sp. species, presenting high degrees of similarity with the species type, described by Martin \& Desser (1990). Using molecular tools have been able to describe new species of Trypanosoma parasitizing amphibians species of genus Leptodactylus from Caatinga and Cerrado biomes and three species of alligators from the Amazon and Pantanal, all in Brazil (Fermino et al. 2015, Attias et al. 2016). Besides, were able to identify the leech of the genus Haementheria as Trypanosoma vector for alligators, being found in the oral cavity of the animals (Fermino et al. 2015). However, more studies using a broad sample of Trypanosoma species and characters are necessary, since the morphometric and morphological similarity presented in the present study does not match the molecular phylogenies presented by Martin et al. (2002), Ferreira et al. (2008) and Spodareva et al. (2018). The present study, records R. major parasitized by trypanosomes, which represents a new vertebrate host for Trypanosoma sp. in Brazil.

Hematophagous diptera can act as vectors of different lineages of Trypanosoma spp., especially for Amazon terrestrial anurans (Ferreira et al. 2008). Rhinella major is a species with predominantly terrestrial habits in the adult phase and uses holes in the ground to shelter, which could increase the chances of contact with hematophagous dipteran. There are evidence that some species of Corethrella may transmit Trypanosoma by feeding on calling frogs and this association is likely an ancient one (Johnson et al. 1993, Borkent 2008). Nevertheless, the mechanism of transmission of these hemoflagellates in the Amazon region is relatively unknown.

More comprehensive studies on the physiological aspects of host response to trypanosomatid infection are needed, as well as studies to improve and extend the taxonomy of this group using molecular tools. It is important to know the diversity of hosts, since their performance can be affected by parasitism.

\section{Acknowledgments}

The authors would like to thank the Coordenação de Aperfeiçoamento de Pessoal de Nivel Superior (CAPES) for the scholarship for Darlison C. Souza. The author Lincoln L. Corrêa thanks for this study had guaranteed support and financial support granted by the project CAPES/Fundação de Amparo à Pesquisa do Estado do 


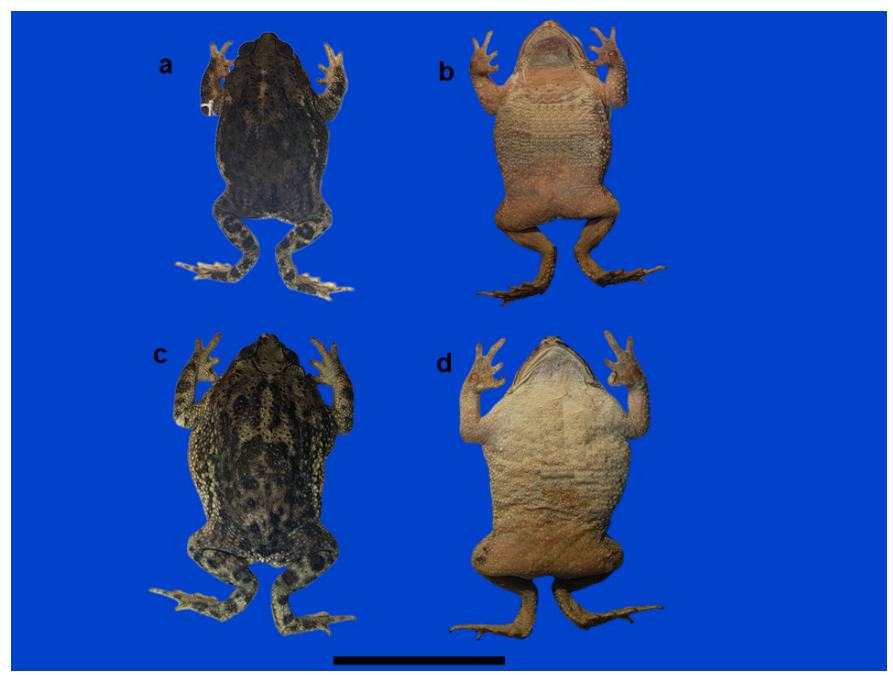

Figure 3. Rhinella

major collected on

the right bank of

the Curuá-Una River.

a - Male in dorsal

position; b - Male

in ventral position;

c - Female in dorsal

position; $d$ - Female in

ventral position (bar

$5 \mathrm{~cm})$.
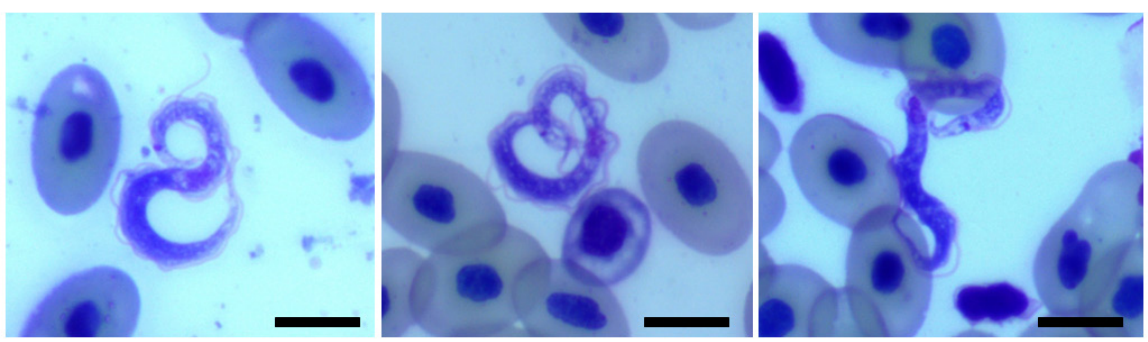

Figure 4. Trypomastigote forms of Trypanosoma sp. observed in the blood circulation of Rhinella major (bar $10 \mu \mathrm{m}$ ).

Table II. Morphometric measurements of the Trypomastigote shape $(n=10)$ of Trypanosoma spp. in Rhinella major from the Curuá-Una Hydroelectric Power Plant, Santarém, western Pará in the Eastern Amazon (Brazil).

\begin{tabular}{|c|c|c|}
\hline Parameters & Mean \pm Deviation & Minimum/Maximum \\
\hline Total body length with flagellum & $65.97 \pm 6.32$ & $53.55-76.47$ \\
\hline Body length along the midline & $51.97 \pm 5.44$ & $43.97-60.83$ \\
\hline $\begin{array}{c}\text { Distance from the center of the nucleus to the posterior } \\
\text { extremity }\end{array}$ & $21.76 \pm 3.21$ & $15.04-26.53$ \\
\hline $\begin{array}{c}\text { Distance from the center of the nucleus to the anterior } \\
\text { extremity }\end{array}$ & $30.22 \pm 3.68$ & $22.86-34.58$ \\
\hline Length of the free flagellum & $12.60 \pm 6.42$ & $13.58-17.92$ \\
\hline Nucleus Length & $3.46 \pm 0.39$ & $2.61-3.95$ \\
\hline Nucleus width in center portion & $2.09 \pm 0.90$ & $1.34-4.64$ \\
\hline Body width in the center of the nucleus & $2.84 \pm 0.94$ & $2.11-5.45$ \\
\hline $\begin{array}{l}\text { Distance from the center of the kinetoplast to the center } \\
\text { of the nucleus }\end{array}$ & $15.27 \pm 2.62$ & $9.20-18.77$ \\
\hline $\begin{array}{c}\text { Distance from the center of the kinetoplast to the } \\
\text { posterior extremity }\end{array}$ & $6.14 \pm 2.55$ & $0-10.13$ \\
\hline Kinetoplast length & $0.80 \pm 0.21$ & $0.46-1.15$ \\
\hline Kinetoplast Width & $0.84 \pm 0.12$ & $0.62-1.05$ \\
\hline
\end{tabular}


Pará (FAPESPA) N. 06/2015 - Process n 88881.160660 / 2017-01.

\section{REFERENCES}

ANDERSON JR \& AYALA SC. 1968. Trypanosome transmitted by Phlebotomus: first report from the Americas. Science 161(3845): 1023-1025.

ATTIAS M, SATO LH, FERREIRA RC, TAKATA CSA, CAMPANER M, CAMARGO EP, TEIXEIRA MMG \& DE SOUZA W. 2016. Developmental and ultrastructural characterization and phylogenetic analysis of Trypanosoma herthameyeri n. sp. of Brazilian Leptodactilydae frogs. J Eukaryot Microbiol 63: 610-622.

BAILEY JK. 1962. Aedes aegypti as a possible new invertebrate host for frog trypanosomes. Exp Parasitol 12(3): 155-163.

BARDSLEY JE \& HARMSEN R. 1973. The trypanosomes of Anura. In: Adv Parasit. Elsevier, p. 1-73.

BERNAL XE \& PINTO CM. 2016. Sexual differences in prevalence of a new species of trypanosome infecting túngara frogs. Int J Parasitol: Parasites and Wildlife 5(1): 40-47.

BORGES AR, LEMOS M, MORAIS DH, SOUTO-PEDRÓN T \& D'AGOSTO A. 2016. In vitro culture and morphology of fish trypanosomes from South American Wetland Areas. SOJ Microbiol Infect Dis 4(2): 1-5.

BORKENT A. 2008. The frog-biting midges of the world (Corethrellidae: Diptera). Zootaxa 1804: 1-456.

BUSH AO, LAFFERTY KD, LOTZ JM \& SHOSTAK AW. 1997. Parasitology meets ecology on its own terms: Margolis et al., Revisited. J Parasitol 83(4): 575-583.

DENSMORE CL \& GREEN DE. 2007. Diseases of amphibians. Ilar Journal 48(3): 235-254.

DESSER SS. 2001. The blood parasites of anurans from Costa Rica with reflections on the taxonomy of their Trypanosomes. J Parasitol 87(1): 152-160.

FERMINO BR ET AL. 2015. Field and experimental evidence of a new caiman trypanosome species closely phylogenetically related to fish trypanosomes and transmitted by leeches. Int J Parasitol Parasites Wildl 4: 368-378.

FERREIRA JIGDAS ET AL. 2015. Anuran trypanosomes: phylogenetic evidence for new clades in Brazil. Syst Parasitol 91(1): 63-70.
FERREIRA RC, CAMPANER M, VIOLA LB, TAKATA CSA, TAKEDA GF \& TEIXEIRA MMG. 2007. Morphological and molecular diversity and phylogenetic relationships among anuran trypanosomes from the Amazonia, Atlantic Forest and Pantanal biomes in Brazil. Parasitol 134(11): 1623-1638.

FERREIRA RC, SOUZA AA, FREITAS RA, CAMPANER M, TAKATA CSA, BARRETT TV, SHAW JJ \& TEIXEIRA MMG. 2008. A phylogenetic lineage of closely related trypanosomes (Trypanosomidae, Kinetoplastida) of anurans and sand flies (Psychodidae, Diptera) sharing the same ecotopes in brazilian Amazonia. J Eukariot Microbiol 55(5): 427-435.

JOHNSON RN, YOUNG DG \& BUTLER JF. 1993. Trypanosome transmission by Corethrella wirthi (Diptera: Chaoboridae) to the green treefrog, Hyla cinerea (Anura: Hylidae). J Med Entomol 30(5): 918-921.

LEAL DDM, O'DWYER LH, RIBEIRO VC, SILVA RJ, FERREIRA VL \& RODRIGUES RB. 2009. Hemoparasites of the genus Trypanosoma (Kinetoplastida: Trypanosomatidae) and hemogregarines in Anurans of the São Paulo and Mato Grosso do Sul States - Brazil. An Acad Bras Cienc 81: 199-206.

LEMOS M, MORAIS DH, CARVALHO VT \& D'AGOSTO M. 2008. First record of Trypanosoma chattoni in Brazil and occurrence of other Trypanosoma species in Brazilian frogs (Anura, Leptodactylidae). J Parasitol 94: 148-151.

MALYSHEVA MN. 2009. Contributions of the fauna of haemoparasites of batrachians (Amphibia, Anura) in Kyrgyzstan. Parazitol 43(1): 32-44.

MARTIN DS \& DESSER SS. 1990. A light and electron microscopic study of Trypanosoma fallisi N. Sp. in toads (Bufo americanus) from Algonquin Park, Ontario. J Protozool 37(3): 199-206.

MARTIN DS \& DESSER SS. 1991. Development of Trypanosoma fallisi in the leech, Desserobdella picta, in toads (Bufo americanus), and in vitro. A light and electron microscopic study. Parasitol Res 77(1): 18-26.

MARTIN DS, WRIGHT ADG, BARTA JR \& DESSER SS. 2002. Phylogenetic position of the giant anuran trypanosomes Trypanosoma chattoni, Trypanosoma fallisi, Trypanosoma mega, Trypanosoma neveulemairei, and Trypanosoma ranarum inferred from 18s rRNA gene sequences. J Parasitol 88(3): 566-571.

MIYATA A \& YOUNG HS. 1990. A new trypanosome, Trypanosoma hosei (Protozoa: Trypanosomatidae), in Rana hosei (Amphibia: Anura: Ranidae) from peninsular Malaysia. Raff Bull Zool 39(1): 131-134.

NARVAES P \& RODRIGUES MT. 2009. Taxonomic revision of Rhinella granulosa species group (Amphibia, Anura, 
Bufonidae), with a description of a new species. Arq Zool 40(1): 1-73.

O'ROURKE DP \& ROSENBAUM MD. 2015. Chapter 18 - Biology and Diseases of Amphibians, Third Edit. Elsevier Inc.

RODRIGUES AFSF, MORAIS DH, CARVALHO VT, D'AGOSTO M \& LEMOS M. 2019. Morphological and morphometric characterization of trypanosomes in Leptodactylus lineatus and Osteocephalus sp. (Anura) from Brazilian Midwest. Rev Bras Zoociências. 20: 1-10.

SAILASUTA A, SATETASIT J \& CHUTMONGKONKUL M. 2011. Pathological study of blood parasites in rice field frogs, Hoplobatrachus rugulosus (Wiegmann, 1834). Vet Med Int 2011: 1-5.

SIDDALL ME \& DESSER SS. 1992. Alternative leech vectors for frog and turtle trypanosomes. J Parasitol 78(3): 562-563.

SPODAREVA VV, GRYBCHUK-IEREMENKO A, LOSEV A, VOTÝPKA J, LUKES J, YURCHENKO V \& KOSTYGOV AY. 2018. Diversity and Evolution of anuran trypanosomes: insights from the study of European species. Parasite Vector 11(1): 447.

WOO PTK. 1969. Trypanosomes in amphibians and reptiles in southern Ontario. Can J Zool 47(5): 981-988.

WRIGHT KM. 2006. Overview of amphibian medicine. In: Mader DR Ed. Reptile Medicine and Surgery. Elsevier, St. Louis, p. 941-971.

ZAR JH. 2010. Bioestatística analysis. New Jersey, Prentice Hall.

\section{How to cite:}

COÊLHO TA, SOUZA DC, KAWASHITA-RIBEIRO RA \& CORRÊA LL. 2021. First record of Trypanosoma sp. (Kinetoplastea: Trypanosomatidae) parasiting Rhinella major in the Brazilian Amazon. An Acad Bras Cienc 93: e20190467. DOI 10.1590/0001-3765202120190467.

\section{TÁSSIO A. COÊLHO'}

https://orcid.org/0000-0002-0264-4526

\section{DARLISON C. DE SOUZA 1}

https://orcid.org/0000-0002-7610-9665

RICARDO A. KAWASHITA-RIBEIRO ${ }^{1,2}$

https://orcid.org/0000-0001-6812-0904

\section{LINCOLN L. CORRÊA ${ }^{1,2}$}

https://orcid.org/0000-0002-6453-4824

${ }^{1}$ Programa de Pós-Graduação em Biodiversidade/ PPGBEES, Universidade Federal do Oeste do Pará, Instituto de Ciências e Tecnologia das Águas/ICTA, Rua Vera Paz, s/n, Salé, 68040-255 Santarém, PA, Brazil

${ }^{2}$ Universidade Federal do Oeste do Pará/UFOPA, Instituto de Ciências e Tecnologia das Águas/ICTA, Rua Vera Paz, s/n, Salé, 68040-255 Santarém, PA, Brazil

\section{Correspondence to: Lincoln Lima Corrêa \\ E-mail: lincorre@gmail.com}

\section{Author contributions}

The authors declare that there is no conflict of interests regarding the publication of the manuscript. The authors state that MSc. Tássio A. Côelho and MSc. Darlison C. de Souza designed the study, collected research data, analyzed the data, wrote, and revised the article. Dr. Lincoln L. Corrêa and Dr. Ricardo A. Kawashita-Ribeiro designed the study, analyzed the data and revised the article. All authors read and approved the final manuscript.

\section{(cc) BY}

Manuscript received on April 24, 2019;

accepted for publication on December 10, 2019 